\title{
Evaluation of the antiproliferative activity of selected 1,2,3-triazole- 4-carboxylic acids - key fragments and precursors of antitumor 1,2,3-triazole-4-carboxamides
}

\author{
N. Pokhodylo, V. Matiychuk \\ Ivan Franko National University of Lviv \\ 4, Hrushevskoho Str., Lviv, Ukraine, 79005
}

\begin{abstract}
Aim. To evaluate in vitro antiproliferative effect of selected 1,2,3-triazole-4-carboxylic acids, which are the key fragments and precursors of antitumor 1,2,3-triazole-4-carboxamides. Methods. Organic synthesis, in vitro cytotoxicity assay, MTT assay, spectrophotometry, statistical analysis. Results. The selected 1,2,3-triazole carboxylic acids and their esters synthesized according to a convenient synthetic procedure were tested for their anticancer activity in NCI60 cell lines within 9 cancer types at the 60 human tumour cell lines panel. These preliminary results allowed identifying the most active compounds and finding the structure-activity relations. The most promising 1,2,3-triazole-4-carboxylic fragments were selected for the design of 1,2,3-triazole-4-carboxamides for screening anticancer activity. Conclusions. The obtained results of antitumour activity of the studied derivatives are interesting for the discovery of selective and active anticancer agents among 1,2,3-triazole-4-carboxamides in terms of a fragment-based drug discovery (FBDD) concept, that proves the necessity of further studies.
\end{abstract}

Ke y w or d s: 1,2,3-triazoles, 1,2,3-triazole-4-carboxamides, 1,2,3-triazole-4-carboxylic acids, anticancer activity, cell proliferation

\section{Introduction}

Currently, the compounds containing the 1,2,3-triazole-4-carboxamide motif are of special interest in medicinal chemistry. For instance, there are the well-known drugs among such compounds: Rufinamide used for the treatment of Lenox-Gastaut syndrome (a form of epilepsy) since 2008 [1], and Carboxyami- dotriazole used as calcium-activated potassium channel activator [2]. Moreover, Carboxyamidotriazole in the form of the orotic acid salt demonstrated high activity against chronic myelocytic leukaemia inhibiting the growth of cells LAMA84R and K562R [3]. Other compounds related to the 1,2,3-triazole-4-carbox-

(C) 2021 N. Pokhodylo et al.; Published by the Institute of Molecular Biology and Genetics, NAS of Ukraine on behalf of Biopolymers and Cell. This is an Open Access article distributed under the terms of the Creative Commons Attribution License (http://creativecommons.org/licenses/by/4.0/), which permits unrestricted reuse, distribution, and reproduction in any medium, provided the original work is properly cited 
amides are promising antiproliferative agents for anticancer studies (selected compounds are shown in Fig. 1). Thus, Elamari et al. tested asymmetric bis-triazoles in vitro for their cytotoxic activity toward the B16 melanoma cells and found the compounds with activity at nanomolar level $(<1 \mu \mathrm{M})[4,5]$. Furthermore, Prasad et al. discovered cytotoxicity of 1-benzyl-N-(2-(phenylamino)pyridin-3-yl)- $1 H$ 1,2,3-triazole-4-carboxamides against the lung cancer A549 cell line and proposed the tubulin polymerization inhibition as the mechanism of cytotoxicity [6]. At the same time, 1,2,3-triazole-4-carboxamides containing podophyllotoxin were screened for the DNA topoisomerase-II $\alpha$ inhibitory activity [7]. In our previous work, we found 5-amino-1H-1,2,3-triazole-4-carboxamides as potent antiproliferative agents toward the CNS cancer SNB-75 cell line [8]. The related condensed [1,2,3] triazolo[1,5-a]pyrimidines were also studied and the compounds with cytotoxic activity were found $[9,10]$. The 5-(trifluoromethyl)$1 H$-1,2,3-triazole-4-carboxamides were discovered as c-Met-targeting and apoptosis-inducing agents for various tumour cell lines (MCF-7, HepG2, A549, H460, HT-29, MKN45 and U87MG) with a 3-5-fold higher activity than the positive control drug foretinib [11, 12]. Taddei et al. reported the compound that exhibited the heat shock protein 90 inhibition [13]. Moreover, among 1-aryl-5-substituted1H-1,2,3-triazole-4-carboxamides, some highly active compounds for various biotargets were found. For example, Duan et al. studied 1-aryl-5-methyl-1,2,3-triazole-4-carboxamide as an inhibitor of ER stress-induced CHOPluciferase [14]. Recently, Bekheit et al. found 4-(4-(hydrazinecarbonyl)-5-methyl-1H-1,2,3- triazol-1-yl)benzenesulfonamide with moderate selectivity toward COX-2 inhibition (selectivity ratio of 6.99) [15]. Cohen et al. discovered $1 H$-1,2,3-triazole-4-carboxamide with therapeutic effect in a zebrafish model of muscular dystrophy that resulted from the mitochondrial permeability transition pore (mtPTP) dysfunction [16, 17]. Furthermore, Obianom et al. discovered 1,2,3-triazole-4-carboxamides as the inhibitors of the $\mathrm{Wnt} / \beta$-catenin signalling pathway [18].

Additionally, the 1,2,3-triazole-4-carboxamide based compounds demonstrated promising results in discovering antimicrobial [19-22], fungicidal [23] and anti-leishmanial agents [24]. The 1,2,3-triazole-4-carboxamides were also found as inhibitors of the acetylcholinesterase activity against Alzheimer's disease [25] and human plasma kallikrein (PKK) [26]. Krajczyk et al. tested the related ribavirin compounds for virus-inhibitory activity [27].

Finally, new PROTACs were synthesised via conjugation of corresponding focal adhesion kinase (FAK) or Bruton's tyrosine kinase (BTK) inhibitors with the E3 ligase ligand through 1,2,3-triazole-4-carboxamide containing linkers and showed rapid and reversible degradation with a picomolar $\mathrm{DC}_{50}$ value in various cell lines in vitro for FAK [28] and BTK [29] respectively.

Thus, the compounds with a 1,2,3-triazole4-carboxamide moiety possess considerable potential for the drug discovery. For this reason, we decided to select and evaluate several 1,2,3-triazole carboxylic acids, which are key fragments and precursors of antitumor 1,2,3-triazole-4-carboxamides for their antiproliferative activity. 
<smiles>NC(=O)c1cn(Cc2c(F)cccc2F)nn1</smiles>

Rufinamide<smiles>NC(=O)c1nnn(Cc2cc(Cl)c(C(=O)c3ccc(Cl)cc3)c(Cl)c2)c1N</smiles>

Carboxyamidotriazole

antiproliferative tubulin polymerization inhibitor

DNA topoisomerase-II inhibitor

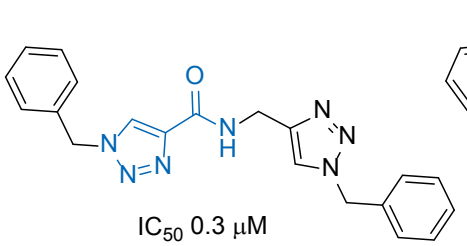

Elamari et al., 2013<smiles>COc1cc(Nc2ncccc2NC(=O)c2cn(Cc3cccc(Oc4ccccc4)c3)nn2)cc(OC)c1</smiles>

Prasad et al., 2019<smiles></smiles>

Reddy et al., 2018<smiles>Cc1ccc(-n2nnc(C(=O)Nc3cc(Cl)ccc3Cl)c2N)cc1</smiles>

Pokhodylo et al., 2014

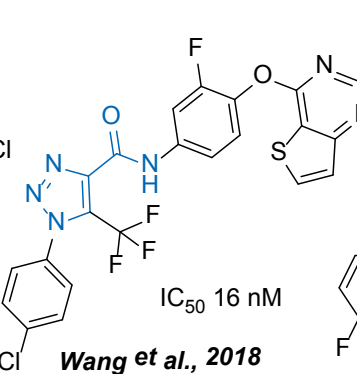

c-Met inhibitors


degradation of FAK

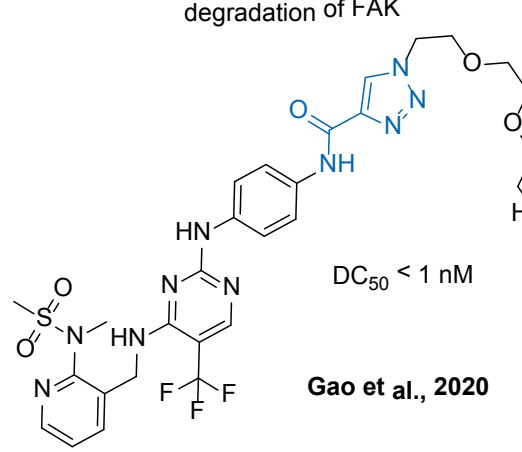

Cohen et al., 2019

PROTACs<smiles>CCCOCCNc1cccc2c1C(=O)N(C1CCC(=O)NC1=O)C2=O</smiles>

Zhou et al., 2014

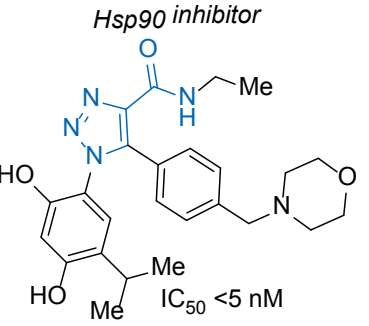

Taddei et al., 2014

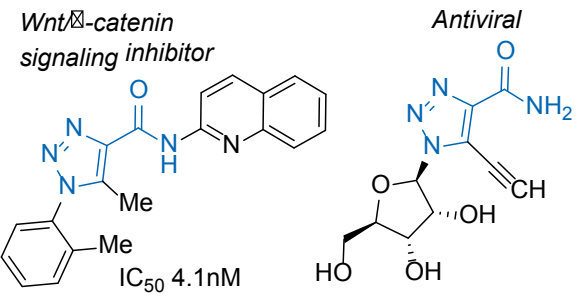

Obianom et al., 2019

Krajczyk et al., 2014

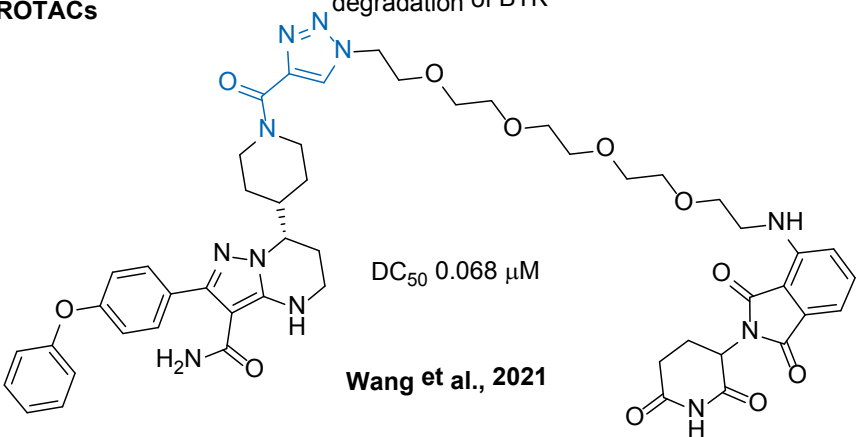

Fig. 1. Biologically active 1-aryl-1H-1,2,3-triazole-4-carboxamides 


\section{Materials and Methods}

Synthesis: All starting materials were purchased from Merck and used without purification. NMR spectra were determined with Varian Mercury 400 (400 MHz) spectrometer, in DMSO-d $\mathrm{d}_{6}$. Melting points were determined in open capillary tubes and are uncorrected. The purity of the compounds was checked by thin-layer chromatography performed with Merck Silica Gel 60 F254 aluminium sheets. The 1,2,3-triazole carboxylic acids and their ester derivatives were designed as building blocks for the synthesis of antitumor 1,2,3-triazole-4-carboxamides. Compounds 1, 2, 4-7 were obtained as described earlier [30] via the reaction of azidoacetamides with $\beta$-ketoesters (Scheme 1, A). Methyl 1-(2-(diethylamino)2-oxoethyl)-1H-1,2,3-triazole-4-carboxylate 3 was prepared via $\mathrm{CuAAC}$ reaction of 2 -azido$\mathrm{N}, \mathrm{N}$-diethylacetamide with methyl propiolate in the presence of a catalytic amount of $\mathrm{CuI}$ and triethylamine as a co-catalyst (Scheme 1, B) [31]. Compounds 8 and 9 were obtained by the reaction of corresponding ethyl 2-azido3-(2-chlorophenyl)propanoate and 2-azidobicyclo[2.2.1] heptane (2-norbornyl azide) with ethyl acetoacetate in DMSO under the $\mathrm{K}_{2} \mathrm{CO}_{3}$ catalyst (Scheme 1, A) [32, 33]. The 1-aryl5-R-1H-1,2,3-triazole-4-carboxylic acids 1012, 14-16 and 17 (Table 2) were synthesised via convenient Dimroth reaction [34-36]. The 5-methyl-1-(thiazol-2-yl)-1H-1,2,3-triazole4-carboxylic acids 18-24 (Table 2) were prepared via the reaction of 2-azido-1,3-thiazoles with ethyl acetoacetate (Scheme 1, A) [37]. The 5-(1-methyl-1,4,5,6-tetrahydropyridin3-yl)-1-phenyl-1H-1,2,3-triazole-4-carboxylate 15 was prepared via quaternization of the pyridine fragment of compound $\mathbf{1 4}$ with meth- $y$ l iodide in acetone and following reduction of pyridinium salt with sodium borohydride (Scheme 1, C) [35].

Synthesis of 5-(pyridin-4-yl)-1-(ptolyl)-1 H-1,2,3-triazole-4-carboxylic acid 13. 4-Methylphenyl azide $1.33 \mathrm{~g}(0.01 \mathrm{~mol})$ and ethyl 3-oxo-3-(pyridin-4-yl)propanoate $1.93 \mathrm{~g}$ $(0.01 \mathrm{~mol})$ were added to the solution of sodium methoxide prepared from methanol ( 25 $\mathrm{mL})$ and sodium $(0.3 \mathrm{~g}, 0.013 \mathrm{~mol})$. The mixture was heated under reflux during $30 \mathrm{~min}$. Then $25 \mathrm{~mL}$ of water was added, and the mixture continued to be refluxed for additional 30 min. Solution was washed with TBME, poured into $15 \mathrm{~mL}$ conc. $\mathrm{HCl}$ and left to a solid formation. The solid was collected by filtration and if required could be recrystallized from diluted ethanol. Yield $87 \%$, m.p. $218-219{ }^{\circ} \mathrm{C}$. ${ }^{1} \mathrm{H}$ NMR (400 MHz, DMSO- $\left.d_{6}\right) \delta 8.55(\mathrm{dd}$, $\left.J=4.5,1.4 \mathrm{~Hz}, 2 \mathrm{H}, \mathrm{H}^{\mathrm{Py}}-3,5\right), 7.31$ (dd, $J=4.4$, $\left.1.5 \mathrm{~Hz}, 2 \mathrm{H}, \mathrm{H}^{\mathrm{Py}}-2,6\right), 7.25(\mathrm{~d}, J=8.5 \mathrm{~Hz}, 2 \mathrm{H}$, $\left.\mathrm{H}^{\mathrm{Py}}-2,6\right), 7.21\left(\mathrm{~d}, J=8.6 \mathrm{~Hz}, 2 \mathrm{H}, \mathrm{H}^{\mathrm{Py}}-3,5\right)$, $2.38(\mathrm{~s}, 3 \mathrm{H}, \mathrm{Me})$. LCMS $\left(\mathrm{ESI}^{+}\right) \mathrm{m} / z 281$ $(\mathrm{M}+\mathrm{H})^{+}$. Anal. Calcd. for $\mathrm{C}_{15} \mathrm{H}_{12} \mathrm{~N}_{4} \mathrm{O}_{2}$ : C, 64.28; H, 4.32; N, 19.99. Found: C, 64.21; H, $4.33 ; \mathrm{N}, 19.94$.

2-\{[(4-(Methoxycarbonyl)-1-phenyl-1H1,2,3-triazol-5-yl)methyl]carbamoyl\}benzoic acid 17. To a solution of phenyl azide $1.19 \mathrm{~g}(0.01 \mathrm{~mol})$ in $4 \mathrm{~mL}$ of dimethyl sulfoxide, dry potassium carbonate $(5.5 \mathrm{~g}, 0.04 \mathrm{~mol})$ and 3-oxo-4-phthalimido-butyric acid methyl ester $2.61 \mathrm{~g}(0.01 \mathrm{~mol}) \mathbf{1}$ were added. The suspension was stirred at $40-50{ }^{\circ} \mathrm{C}$ until [the] monitoring by TLC indicated that all starting materials had disappeared (7-12 h). Then the mixture was cooled to $5{ }^{\circ} \mathrm{C}$, diluted with 15 $\mathrm{mL}$ of water, washed with TBME and acidified with hydrochloric acid to a $\mathrm{pH} \sim 1$. The formed 
precipitate of pure 17 was filtered. Yield $71 \%$, m.p. $238-239{ }^{\circ} \mathrm{C} .{ }^{1} \mathrm{H}$ NMR $(400 \mathrm{MHz}$, DMSO- $\left.d_{6}\right) \delta 12.96(\mathrm{~s}, 1 \mathrm{H}, \mathrm{COOH}), 8.60(\mathrm{~s}$, 1H, NH), 7.89-7.39 (m, Hz, 8H, H ${ }^{\text {Arom. }}$ ), 6.95 (br.s, 1H, HArom), 4.76 (s, 2H, $\left.\mathrm{CH}_{2}\right), 3.90$ (s, $3 \mathrm{H}, \mathrm{OMe})$. LCMS $\left(\mathrm{ESI}^{+}\right) \mathrm{m} / z 381(\mathrm{M}+\mathrm{H})^{+}$. Anal. Calcd. for $\mathrm{C}_{19} \mathrm{H}_{16} \mathrm{~N}_{4} \mathrm{O}_{5}: \mathrm{C}, 60.00 ; \mathrm{H}$, 4.24; N, 14.73. Found: C, 60.07; H, 4.21; N, 14.74 .

\section{Anticancer assay}

According to the protocol of the Drug Evaluation Branch, National Cancer Institute, Bethesda, a primary anticancer assay was performed within nine cancer types at approximately 60 human tumour cell lines panel. The tested compounds were added to the culture at a single concentration $\left(10^{-5} \mathrm{M}\right)$ and left for 48 $h$ incubation. Sulforhodamine B (SRB) was used as a protein binding dye for the end-point determinations. The percent of growth of the treated cells when compared to the untreated control cells was taken as a result for each tested compound. The percentage growth was evaluated spectrophotometrically versus controls not treated with test agents. Growth percent of 100 corresponds to the growth seen in untreated cells. Growth percent of 0 indicates the absence of net growth over the course of the assay (i.e. equal to the number of cells at time zero). Growth percent of -100 results when all cells are killed.

\section{Cell proliferation (MTT) assay}

In vitro evaluation of anticancer activity of the synthesized compounds and doxorubicin, used as a reference drug control, towards cancer cell lines was carried out by the MTT test [38]. Tumour cells were seeded for $24 \mathrm{~h}$ in $96-$ well microtiter plates at a concentration of 5,000 substrate-dependent cells/well or 10,000 suspension cells/well $(100 \mu \mathrm{L} /$ well $)$. After that, cells were incubated for $72 \mathrm{~h}$ with various additions of the synthesized compounds ( 0 $50 \mu \mathrm{M})$. MTT, converted to dark violet, water insoluble MTT formazan by the mitochondrial dehydrogenases, was used to determine viable cells according to the Sigma-Aldrich protocol. Absorbance Reader BioTek ELx800 (BioTek Instruments, Inc, Winooski, VT, USA) was used for measurement of the reaction results.

\section{Results and Discussion}

\section{Chemistry}

The compounds presented in the article were obtained using simple and convenient synthetic protocols based on the Dimroth reaction. Diversity of azides and $\beta$-keto esters can be used for substituent variation in all positions of the triazole ring. The reaction is useful for the preparation of the heterocyclic, aromatic and aliphatic 1,2,3-triazole carboxylic acids. The method is well suited for the concept of diversity-oriented synthesis (DOS) and allows obtaining a large number of such acids as convenient structural blocks in the synthesis of carboxamides for drug discovery. The synthesis of acids can be described by the General Scheme 1. Noteworthy, ester formed during the cyclization can be in situ hydrolysed to the corresponding acid or kept as ester depending on the reaction conditions. In particular, the ester is the main product when the reaction is performed in dry DMSO with $\mathrm{K}_{2} \mathrm{CO}_{3}$ as a catalyst. Compounds $\mathbf{1 3}$ and 17 were obtained in this work for the first time. Their structure 
(A)

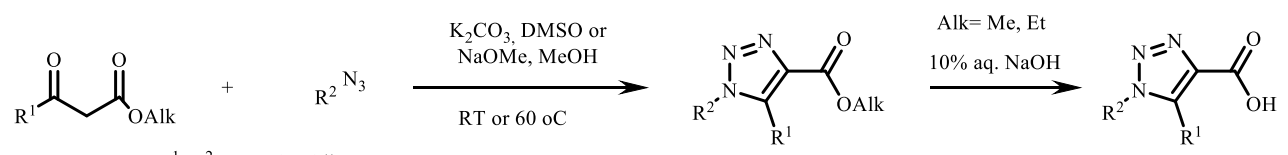

$\mathrm{R}^{1}, \mathrm{R}^{2}$ - Het, Ar, Alk

$\mathbf{2 , 4 - 8 , 1 4 , 1 7}$

$1,3,9-13,16,18-24$

等

1<smiles>CCOC(=O)c1nnn(CC(N)=O)c1[N+](=O)[O-]</smiles>

2

$\left.\underbrace{}_{\mathrm{H}} \mathrm{H}_{\mathrm{Me}}^{\mathrm{N}}\right|_{\mathrm{OEt}} ^{\mathrm{N}}$

4<smiles>COC(=O)c1nnn(CC(=O)NC(C)C)c1CCc1ccccc1</smiles><smiles>CNC(=O)Cn1nnc(C(=O)OC)c1COc1ccccc1</smiles><smiles>COC(=O)c1nnn(CC(N)=O)c1CCNC(=O)c1ccccc1C(=O)O</smiles>

(B)<smiles>CCN(CC)C(=O)CNCCN(CC)C(=O)Cn1cc(C(=O)OC)nn1</smiles><smiles>O=C(O)c1nnn(-c2ccc(Cl)cc2)c1-c1ccco1</smiles>

12<smiles>Cc1ccc(-n2nnc(C(=O)O)c2-c2ccncc2)cc1</smiles>

13<smiles>Cc1c(C(=O)O)nnn1C1CC2CCC1C2</smiles>

9<smiles>O=C(O)c1nnn(-c2ccc(Cl)cc2)c1C(F)(F)F</smiles><smiles>Cc1ccc(-n2nnc(C(=O)O)c2C2CCCO2)cc1</smiles>

11<smiles>COC(=O)c1nnn(-c2ccccc2)c1CNC(=O)c1ccccc1C(=O)O</smiles>

17<smiles>N#Cc1c(C(=O)O)nnn1-c1nccs1</smiles>

18<smiles>CCOC(=O)c1nnn(-c2ccccc2)c1-c1cccnc1</smiles>

14<smiles>Cc1ccc(-n2nnc(C(=O)O)c2-c2ccc3c(c2)OCO3)cc1</smiles>

16<smiles>Cc1ccc(Cc2cnc(-n3nnc(C(=O)O)c3C)s2)cc1</smiles>

19<smiles>Cc1c(C(=O)O)nnn1-c1ncc(Cc2ccccc2)s1</smiles>

20<smiles>Cc1cccc(Cc2cnc(-n3nnc(C(=O)O)c3C)s2)c1</smiles><smiles>Cc1c(C(=O)O)nnn1-c1ncc(Cc2ccc(Cl)cc2)s1</smiles>

22<smiles>Cc1c(C(=O)O)nnn1-c1nc(-c2ccccc2)cs1</smiles>

23

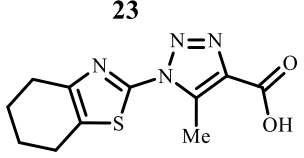

24<smiles>CCOC(=O)c1nnn(-c2ccccc2)c1C1=CCCN(C)C1</smiles>

Scheme 1. Synthesis of 1,2,3-triazole carboxylic acids and their esters 
was confirmed by NMR, LCMS and elemental analysis.

\section{Evaluation of antiproliferative activity in vitro}

The synthesized 24 examples of 1,2,3-triazole carboxylic acids and their esters 1-24 were submitted and evaluated at the single concentration of $10^{-5} \mathrm{M}$ towards a panel of approximately sixty cancer cell lines. The human tumour cell lines were derived from nine different cancer types: leukaemia, non-small cell lung, colon, CNS, melanoma, ovarian, renal, prostate and breast cancers. Primary anticancer assays were performed according to the US NCI protocol (http://dtp.nci.nih.gov), which was described elsewhere [39-42]. The results for each compound are reported as growth percentage (GP) in Table 1. The range of growth (\%) shows the lowest and highest growth that was found among different cancer cell lines.

Initially, triazole acids containing a fragment of an acetamide at position 1 of the triazole ring were tested. For note, such a scaffold is found in the compound that possessed an antimicrobial effect [19]. The 1-(2-amino2-oxoethyl)-1 $H$-1,2,3-triazole-4-carboxylic acids showed mostly low antiproliferative activity, but had a slight effect on the lung cancer cells NCI-H522 line, inhibiting an average growth by $75 \%$. One of the most active compounds, the ethyl 5-methyl-1-(2-oxo-2- (phenylamino)ethyl)-1H-1,2,3-triazole-4-carboxylate, inhibited $69.80 \%$ NCI-H522 cells growth. The ethyl 1-(3-(3-(2-chlorophenyl)1-ethoxy-1-oxopropan-2-yl)-5-methyl- $1 \mathrm{H}$ 1,2,3-triazole-4-carboxylate 8 with $68 \%$ growth percent value was the most active among ester derivatives. It is also important to note that the introduction of large substituents at position 5 of the triazole leads to a decrease in the activity (compound 5, 6). Interestingly, the replacement of the acetic moiety with norbornane led to a change in the targeted cells line. Thus, compound 9 inhibited the kidney cancer cells A498 and UO-31 lines growth ( $\mathrm{GP}=68.12 \%$ and $75.54 \%$ respectively). Among the selected 1-aryltriazole acids, several of them were the motif of scaffolds of molecules that showed high antitumour activity. For example, 1-(4-chlorophenyl)-5-(trifluoromethyl)-1H-1,2,3-triazole-4-carboxylic acid 10 is a structural fragment of 1-(4-chlorophenyl)-N-(3-fluoro-4-(thieno[3,2-d]pyrimidin-4-yloxy)phenyl)-5-(trifluoromethyl)- $1 \mathrm{H}$ 1,2,3-triazole-4-carboxamide, which was found [to be the] selective inhibitor of the c-Met, inducing apoptosis of various tumour cell lines (MCF-7, HepG2, A549, H460, HT29, MKN-45 and U87MG) [11]. The 1-(4-chlorophenyl)-5-(trifluoromethyl)-1 $H$ 1,2,3-triazole-4-carboxylic acid $\mathbf{1 0}$ possessed the highest activity among the tested 1-aryl1,2,3-triazole acids targeting the lung cancer NCI-H522 cells with GP value of $68.09 \%$. Another acid that had a similar value of growth inhibition (GP $=70.01 \%)$ and also acted on [the] NCI-H522 cells, contained a tetrahydrofuran-2-yl substituent in position 5. The ethyl 1-phenyl-5-(pyridin-3-yl)-1H-1,2,3-triazole4-carboxylate, which inhibited the growth of these cells by $30 \%(\mathrm{GP}=70.94 \%)$, demonstrated similar growth value. In general, this NCI-H522 cell line was the most sensitive to such molecular scaffolds $(\mathbf{1 0 - 1 4}, \mathbf{1 7})$ and the average growth was $75.52 \%$, the percent of growth was from 68.09 to $86.18 \%$. Noteworthy, several compounds 10-13, 17 inhibited the 
Table 1. Anticancer screening data of most active 1,2,3-triazole-4-carboxylic acids at the concentration of $10^{-5} \mathrm{M}$

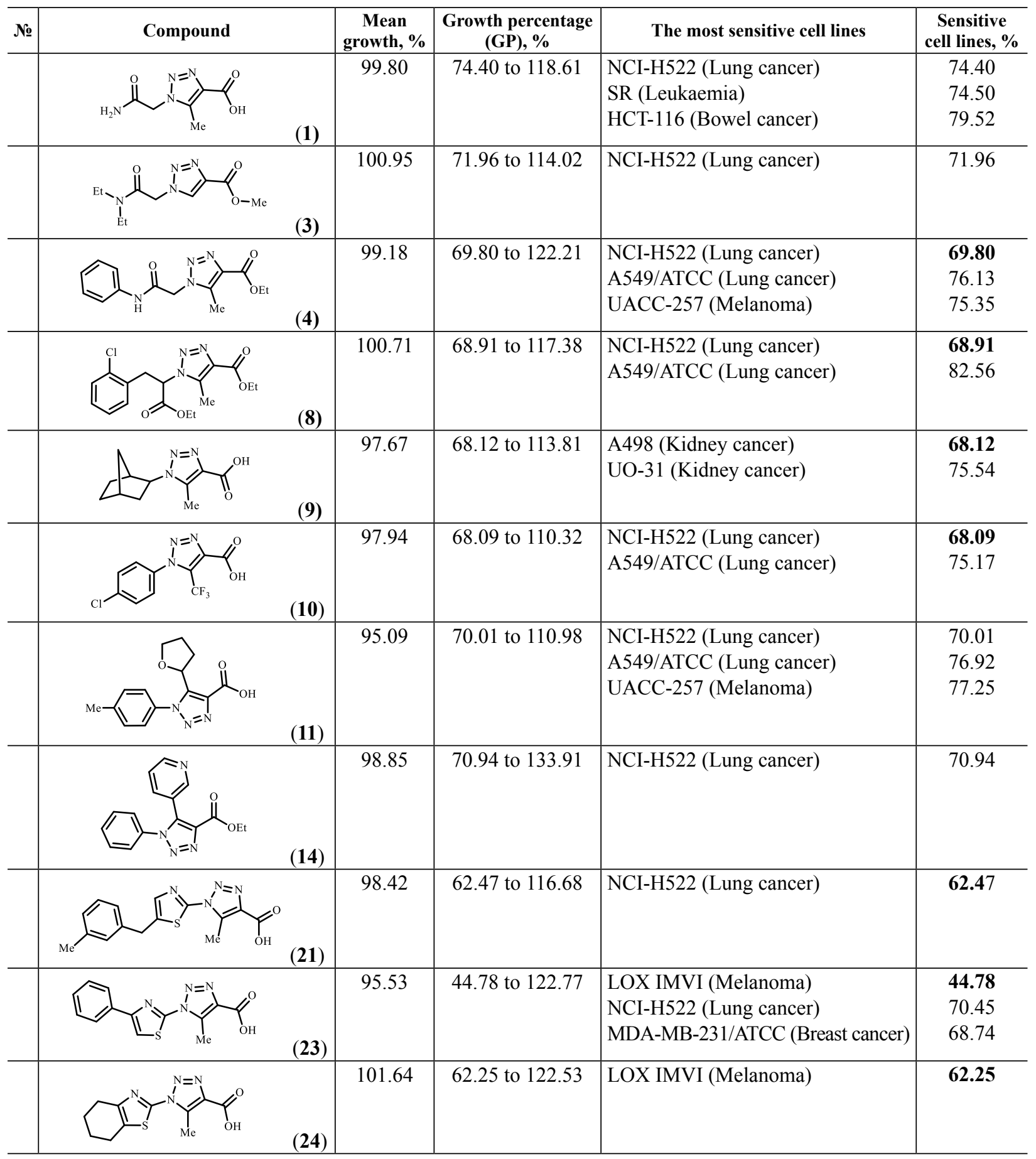


growth of A549/ATCC cell lines (lung cancer), and two compounds 15,16 were weakly active toward UO-31 (kidney cancer). Among the studied by us triazole carboxylic acids, 5-methyl-1-(thiazol-2-yl)-1H-1,2,3-triazole-4-carboxylic acid turned out to be the most active. For example, 5-methyl-1-(5-(3-methylbenzyl)thiazol-2-yl)-1H-1,2,3-triazole-4-carboxylic acid 19 inhibited the growth of NCI-H522 (lung cancer) cells by almost $40 \%(\mathrm{GP}=62.47 \%)$. Noteworthy, 1,2,3-triazoles bearing 5-benzyl-1,3-thiazol-2-yl fragments are promising agents toward tumour cells. For instance, we have recently found that $\mathrm{N}-(5$-benzyl-1,3thiazol-2-yl)-4-(5-methyl-1H-1,2,3-triazol1 -yl)benzamide inhibited the growth of the colon cancer cell lines [43]. Additionally, the compounds 5-methyl-1-(4-phenylthiazol2-yl)-1H-1,2,3-triazole-4-carboxylic acid 23 and 5-methyl-1-(4,5,6, 7-tetrahydrobenzo[d] thiazol-2-yl)-1H-1,2,3-triazole-4-carboxylic acid 24 showed a significant inhibitory effect on the LOX IMVI (Melanoma) cells (GP = $=44.78 \%$ and $62.25 \%$, respectively). Finally, it can be concluded that such a fragment is quite promising for the creation of compounds for screening of antiproliferative properties.

According to our results, the acids display slight or low activity in the in vitro screen on the tested cell lines and are significantly less active than the corresponding structurally similar amides. One of the reasons for this may be their high acidity, which is a consequence of the influence of the electron-acceptor triazole ring on the carboxylic group. This can lead to their non-selective binding, reducing their cell permeability and other side processes with their participation in the cell. The fact that in the case of 1-(thiazol-2-yl)-1H-1,2,3- triazole-4-carboxylic acid the antiproliferative effect was higher can also be explained by the abovementioned thesis, because such compounds are zwitterionic. On the other hand, the highest value of growth inhibition in the case of 1-(4-chlorophenyl)-5- $\mathrm{CF}_{3}-1 \mathrm{H}$-1,2,3-triazole-4-carboxylic acid in comparison with other aryl derivatives, may indicate a decisive role of such motif in the interaction with biotargets (such as c-Met). These motifs are selected for creating new derivatives.

\section{Conclusion}

In the present article, in vitro anticancer activity of the selected 1,2,3-triazole carboxylic acids and their esters was evaluated. The preliminary results allowed identifying the most active compounds and finding the structureactivity relations. The obtained data on the antitumour activity of such derivatives are interesting for the discovery of selective and active anticancer agents among the fused 1,2,3-triazole-4-carboxamides in terms of a fragment-based drug discovery (FBDD) concept and prove the necessity of further studies.

\section{Acknowledgments}

We are grateful to Dr. V.L. Narayanan from National Cancer Institute, Bethesda, MD, USA, for in vitro evaluation of anticancer activity.

\section{Funding}

The authors are greatly thankful to National Research Foundation of Ukraine (project 2020.01/0166 "New azole and cage-like agents against cancer and pathogenic microorganisms") and the Ministry of Education and Science of Ukraine (Grant No 0121U107777) for financial support. 


\section{REFERENCES}

1. Wheless $J W$, Vazquez B. Rufinamide: a novel broadspectrum antiepileptic drug. Epilepsy Curr. 2010; 10: $1-6$.

2. Calderone V, Fiamingo FL, Amato G, Giorgi I, Livi O, Martelli A, Martinotti E. 1,2,3-Triazol-carboxanilides and 1,2,3-triazol-(N-benzyl)-carboxamides as BK-potassium channel activators. XII Eur $J$ Med Chem. 2008; 43: 2618-26.

3. Corrado C, Flugy AM, Taverna S, Raimondo $S$, Guggino G, Karmali R, De Leo G, Alessandro R. Carboxyamido-triazole-Orotate Inhibits the Growth of Imatinib-Resistant Chronic Myeloid Leukaemia Cells and Modulates Ex-osomes-Stimulated Angiogenesis. PLoS One. 2012; 7: 1-13.

4. Elamari H, Meganem F, Herscovici J, Hirard C. Chemoselective preparation of disymmetric bistriazoles from bisalkynes. Tetrahedron Lett. 2011; 52: 558-60.

5. Elamari H, Slimi R, Chabot GG, Quentin L, Scherman $D$, Girard $C$. Synthesis and in vitro evaluation of the po-tential anticancer activity of mono- and bis-1,2,3-triazole derivatives of bis-alkynes. Eur $J$ Med Chem. 2013; 60: 360-4.

6. Prasad B, Lakshma V, Srikanth PS, Baig MF, Reddy NS, Babu KS, Kamal A. Synthesis and biological evaluation of 1-benzyl-N-(2-(phenylamino)pyridin3yl)-1H-1,2,3-triazole-4-carboxamides as antimitotic agents. Bioorg Chem. 2019; 83: 535-48.

7. Reddy VG, Bonam SR, Reddy TS, Akunuri R, Naidu VGM, Nayak VL, Bhargava SK, Kumar HS, Sriha-

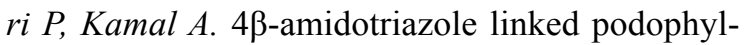
lotoxin congeners: DNA topoisomerase-II $\alpha$ inhibition and potential anti-cancer agents for prostate cancer. Eur J Med Chem. 2018; 144: 595-611.

8. Pokhodylo N, Shyyka O, Matiychuk V. Synthesis and anticancer activity evaluation of new 1,2,3-triazole4carboxamide derivatives. Med Chem Res. 2014; 23 : 2426-38.

9. Shyyka OYa, Pokhodylo NT, Finiuk NS. Anticancer activity evaluation of thie-no[3,2-e][1,2,3] triazolo[1,5-a]pyrimidines and thieno[2,3-e][1,2,3] triazolo[1,5-a]pyrimidine derivatives. Biopolym Cell. 2019; 35: 321-30.
10. Pokhodylo N, Shyyka O, Finiuk N, Stoika R. Selected 5-amino-1-aryl-1H-1,2,3-triazole scaffolds as promising antiproliferative agents. Ukr Biochem $J$. 2020; 92 (5): 23-32.

11. Wang L, Xu S, Liu X, Chen X, Xiong H, Hou $S$, Zou $W$, Tang $Q$, Zheng $P$, Zhu $W$. Discovery of thinopyrimi-dine-triazole conjugates as c-Met targeting and apoptosis inducing agents. Bioorg Chem, 2018; 77: 370-80.

12. Zhou S, Liao H, Liu M, Feng G, Fu B, Li R, Cheng $M$, Zhao Y, Gong P. Discovery and biological evaluation of novel 6,7-disubstituted-4-(2-fluorophenoxy) quinoline derivatives possessing 1,2,3-triazole-4-carboxamide moie-ty as c-Met kinase inhibitor. Bioog Med Chem. 2014; 22: 6438-52.

13. Taddei M, Ferrini S, Giannotti L, Corsi M, Manetti F, Giannini G, Vesci L, Milazzo FM, Alloatti D, Guglielmi MB, Castorina M. Synthesis and Evaluation of New Hsp90 Inhibitors Based on a 1,4,5-Trisubstituted 1,2,3-Triazole Scaffold. J Med Chem. 2014; 57: 2258-74.

14. Duan H, Arora D, Li Y, Setiadi H, Xu D, Lim HY, Wang $W$. Identification of 1,2,3-triazole derivatives that protect pancreatic $\beta$ cells against endoplasmic reticulum stress-mediated dysfunction and death through the inhibition of C/EBP-homologous protein expression. Bioorg Med Chem. 2016; 24: 2621-30.

15. Bekheit MS, Mohamed HA, Abdel-Wahab BF, Fouad MA. Design and synthesis of new 1,4,5-trisubstituted tri-azole-bearing benzenesulphonamide moiety as selective COX-2 inhibitors. Med Chem Res. 2021; 30: 1125-1138.

16. Cohen M, Forte M, Sileikyte J, Nilsen A, Devereaux J, Bernardi P. Second generation inhibitors of mitochondrial permeability transition pore with improved plasma stability Patent WIPO 2021; WO 2021016594.

17. Sileikyte J, Devereaux J, de Jong J, Schiavone $M$, Jones K, Nilsen A, Bernardi P, Forte M, Cohen M. $\mathrm{S}$. Second-generation inhibitors of the mitochondrial permeability transition pore with improved plasma stability. ChemMedChem 2019; 14 (20): 1771-82.

18. Obianom ON, Ai Y, Li Y, Yang W, Guo D, Yang H, Sakamuru S, Xia M, Xue F, Shu Y. Triazole-based inhibitors of the $\mathrm{Wnt} / \beta$-catenin signaling pathway 
improve glucose and lipid metabolisms in diet-induced obese mice J Med Chem. 2019; 62: 727-41.

19. $M o$ o $C Y$. "Make antibiotics great again: Combating drug resistance by targeting Lexa, a regulator of bacterial evolution" Publicly Accessible Penn Dissertations. 2016; 2489.

20. Jadhav RP, Raundal HN, Patil AA, Bobade VD. Synthesis and biological evaluation of a series of 1,4-disubstituted 1,2,3-triazole derivatives as possible antimicrobial agents. $J$ Saudi Chem Soc. 2017; 21: 152-9.

21. Sall C, Ayé M, Bottzeck O, Praud A, Blache Y. Towards smart biocide-free anti-biofilm strategies: Click-based synthesis of cinnamide analogues as anti-biofilm compounds against marine bacteria. Bioorg Med Chem Lett. 2018; 28: 155-9.

22. Pokhodylo N, Manko N, Finiuk N, Klyuchivska O, Matiychuk V, Obushak M, Stoika R. Primary discove-ry of 1-aryl-5-substituted-1H-1,2,3-triazole4-carboxamides as promising antimicrobial agents. J Mol Struct. 2021; Art. 131146.

23. Wang Z-J, Gao Y, Hou Y-L, Zhang C, Yu S-J, Bian Q, Li Z-M, Zhao $W-G$. Design, synthesis, and fungicidal eval-uation of a series of novel 5-methyl-1H1,2,3-trizole-4-carboxyl amide and ester analogues. Eur J Med Chem. 2014; 86: 87-94.

24. Maji K, Abbasi M, Podder D, Datta R, Haldar D. Potential antileishmanial activity of a triazole-based hybrid peptide against leishmania major. ChemistrySelect. 2018; 3: 10220-10225.

25. de Freitas Silva M, Lima ET, Pruccoli L, Castro NG, Guimaraes MJR, da Silva FMR, Nadur NF, Luiz de Azevedo L, Kummerle AE, Guedes IA, Dardenne LE, Gontijo VS, Tarozzi A, Viegas C. Design, synthesis and biological evaluation of novel triazole $\mathrm{N}$-acylhydrazone hybrids for Alzheimer's disease. Molecules. 2020; 25(14): 3165.

26. Eckhardt M, Gollner A, Langkopf E, Wagner $H$, Wiedenmayer D. Preparation of $\mathrm{N}-(1 \mathrm{H}, 4 \mathrm{H}, 5 \mathrm{H}, 6 \mathrm{H}-$ cyclopenta[c]pyrazol-6-yl)heteroaromatic carboxamide derivatives as plasma kallikrein inhibi-tors. Patent WIPO 2020, WO 2020035540

27. Krajczyk A, Kulinska K, Kulinski T, Hurst BL, Day CW, Smee DF, Ostrowski T, Januszczyk P, Zeidler J. Antivi-rally active ribavirin analogues 4,5-disubstituted 1,2,3-triazole nucleosides: bio- logical evaluation against certain respiratory viruses and computational modelling. Antivir Chem Chemother. 2014; 23: 161-71.

28. Gao H, Wu Y, Sun Y, Yang Y, Zhou G, Rao Y. Design, Synthesis, and Evaluation of Highly Potent FAKTargeting PROTACs. ACS Med Chem Lett. 2020; 11 (10): 1855-62.

29. Wang H, Huo C, Guo Y, Qi R, Wang Z. Degradation of bruton's tyrosine kinase (BTK) by conjugation of BTK inidbitors with E3 ligase ligand and methods of use. Patent WIPO 2021; WO 2021018018.

30. Pokhodylo NT, Savka RD, Obushak MD. Synthesis of (1H-1,2,3-Triazol-1-yl)acetic acid derivatives. Russ J Org Chem. 2020; 56 (5): 1421-31.

31. Pokhodylo N, Tupychak M, Shyyka O, Obushak M. Convenient synthesis of 2-(4-amino-1H-1,2,3-triazol-1-yl)acetic acid. Visnyk of the Lviv University. Series Chemistry. 2019; 60 (2): 285-90.

32. Pokhodylo NT, Savka RD, Obushak MD. One-pot synthesis of alkyl 3-aryl-2-(4-phenyl-1H-1,2,3-triazol-1-yl)propanoates. Russ J Org Chem. 2017; 53 (5): 734-7.

33. Pokhodylo NT, Matiichuk VS, Obushak MD. Convenient synthesis of 1-norbornyl-5-R-1H-1,2,3-triazole-4-carboxylic acids. Russ J Org Chem. 2017; 53 (3): 481-3.

34. Pokhodylo NT, Shyyka OYa, Matiychuk VS, Obushak MD, Pavlyuk VV. A novel base-solvent controlled che-moselective azide attack on an ester group versus keto in alkyl 3-substituted 3-oxopropanoates: Mechanistic in-sights. ChemistrySelect. 2017; 2 (21): 5871-6.

35. Pokhodylo N. Synthesis of 1H-1,2,3-triazole-4-carboxylic acid derivatives with hydrogenated pyridine fragment Visnyk of the Lviv University. Series Chemistry. 2018; 59(2):286-93.

36. Pokhodylo NT, Shyyka OY, Savka RD, Obushak MD. 2-Azido-1,3,4-thiadiazoles, 2-azido-1,3-thiazoles, and aryl azides in the synthesis of 1,2,3-triazole4-carboxylic acids and their derivatives. Russ. J. Org. Chem. 2018; 54 (7): 1090-9.

37. Pokhodylo NT, Savka RD, Pidlypnyi NI, Matiychuk VS, Obushak MD. Synthesis of 2-azido-1,3thiazoles as 1,2,3-triazole Precursors. Synth Commun. 2010; 40 (3): 391-9. 
38. Liu X, Zu YG, Fu YJ, Yao LP, Gu CB, Wang W, Efferth $T$. Antimicrobial activity and cytotoxicity towards cancer cells of Melaleuca alternifolia (tea tree) oil. Eur Food Res Technol. 2009; 229: 247-53.

39. Monks A, Scudiero D, Skehan P, Shoemaker R, Paull K, Vistica D, Hose C, Langley J, Cronise P, Vaigro-Wolff $A$, et al. Feasibility of a high-flux anticancer drug screen using a diverse panel of cultured human tumor cell lines. J Natl Cancer Inst. 1991; 83(11): 757-66.

40. Boyd MR, Paull KD. Some practical considerations and applications of the National Cancer Institute in vitro anticancer drug discovery screen. Drug Dev Res. 1995; 34(2): 91-109.

41. Boyd MR. The NCI In vitro anticancer drug discovery screen. In: Ed. Teicher BA. Anticancer Drug Development Guide. Cancer Drug Discovery and Development. Totowa, NJ: Humana Press, 1997. 23-43.

42. Shoemaker RH. The NCI60 human tumour cell line anticancer drug screen. Nat Rev Cancer. 2006; 6(10): 813-23.

43. Pokhodylo N, Shyyka O, Matiychuk V. Synthesis of 1,2,3-triazole derivatives and evaluation of their anticancer activity. Sci Pharm. 2013; 81(3): 663-76.

\section{Оцінка антипроліферативної активності вибраних 1,2,3-триазол-4-карбонових кислот - ключових фрагментів та попередників протипухлинних 1,2,3-триазол-4-карбоксамідів}

Н. Т. Походило, В. С. Матійчук

Мета. Оцінити in vitro антипроліферативну дію відібраних 1,2,3-триазол-карбонових кислот, які є ключових фрагментами та попередниками протипухлинних 1,2,3-триазол-4-карбоксамідів. Методи. Органічний синтез, аналіз цитотоксичності in vitro, аналіз МТT, спектрофотометрія, статистичний аналіз. Результати. Відібрані 1,2,3-триазол-4-карбонові кислоти та їх ефіри, синтезовані відповідно до зручної синтетичної процедури, були протестовані на їх протипухлинну активність на 60 лініях ракових клітин. Попередні результати дозволили виявити найбільш активні сполуки та знайти взаємозв'язок між структурою та активністю. Найбільш активні 1,2,3-триазол-4-карбонові кислоти обрані, як перспективні для проектування 1,2,3-триазол4-карбоксамідів для скринінгу протипухлинної активності. Висновки. Отримані результати протипухлинної активності таких похідних цікаві для відкриття активних протипухлинних агентів серед 1,2,3-триазол-4карбоксамідів з точки зору концепції фрагмент-орієнтованого дизайну лікарських засобові (FBDD) та підтверджують необхідність подальших досліджень.

Кл юч о в і с л ов а: 1,2,3-триазоли, 1,2,3-триазол-4карбоксаміди, 1,2,3-триазол-4-карбонові кислоти, протипухлинна активність, клітинна проліферація

\section{Оценка антипролиферативной активности выбранных 1,2,3-триазол-4-карбоновых кислот - ключевых фрагментов и предшественников противоопухолевых 1,2,3-триазол-4-карбоксамидов}

Н. Т. Походыло, В. С. Матийчук

Цель. Оценить in vitro антипролиферативное действие отобранных 1,2,3-триазол-карбоновых кислот, которые являются ключевыми фрагментами и предшественниками противоопухолевых 1,2,3-триазол-4-карбоксамидов. Методы. органический синтез, анализ цитотоксичности in vitro, анализ МТТ, спектрофотометрия, статистический анализ. Результаты. выбранные 1,2,3-триазолкарбоновые кислоты и их сложные эфиры, синтезированные в соответствии с удобной синтетической процедурой, были протестированы на их противораковую активность 60 линиях раковых клеток. Предварительные результаты позволили идентифицировать наиболее активные соединения и установить взаимосвязь между структурой и активностью. Наиболее активные 1,2,3-триазол-4-карбоновые кислоты выбраны, как перспективные для проектирования 1,2,3-триазол-4-карбоксамидов для скрининга противоопухолевой активности. Выводы. Полученные результаты противоопухолевой активности таких производных интересные для открытия активных противоопухолевых агентов среди 1,2,3-триазол-4-карбоксамид с точки зрения концепции фрагмент-ориентированного дизайна лекарственных средству (FBDD) и подтверждают необходимость дальнейших исследований.

Кл юч е в ы е с с о в а: 1,2,3-триазолы, 1,2,3-триазол-4-карбоксамиды, 1,2,3-триазол-4-карбоновые кислоты, противораковая активность, пролиферация клеток

Received 20.02.2021 